\title{
A comparison of calcium and phosphorus requirements according to different standards in dry cows
}

\author{
Stefania Kinal ${ }^{1}$, J. Preś', A. Korniewicz ${ }^{2}$, Ewa Chrząszez ${ }^{2}$ \\ and T. Kistowski ${ }^{2}$ \\ ' Department of' Animal Nutrition and Feed Management, \\ Wroclaw Agricultural University \\ Norwida 25/27; 50-375 Wroclaw, Poland \\ ${ }^{2}$ Experimental Station of the Research Institute of Animal Production \\ Czechnica, 55-()11 Siechnice, Poland
}

(Received 1 June 1995; accepted 12 January 1996)

\section{SUMMARY}

Twenty-four dry cows were divided into 3 groups and fed maize silage, meadow hay and ground barlcy in amounts covering their nutritients, calcium and phosphorus requirements according to INRA, DI.G or NRC standards. Mineral mixture - Polfamix, produced according to our formula, $\mathrm{NaCl}$, limestone and ammonium phosphate were used as vitamin-mineral additives. The digestibility of dietary nutrients and nitrogen and mineral $(\mathrm{Ca}, \mathrm{P}, \mathrm{Mg}, \mathrm{Na}, \mathrm{Zn}$ and $\mathrm{Cu})$ balance were determined in cach cow 3-4 wecks before calving.

Nutrients digestibility, calcium absorption $(46.3 \%)$ and retention $(25 \mathrm{~g} / \mathrm{d} / \mathrm{cow})$ were higher in cows fed according to INRA standards than using the DLG and NRC systems. In cows from all groups, absorption (14-24\%) and retention (3-7 g/d/cow) of phosphorus were low, but the highest values were in cows fed according to the INRA system. True absorption of $\mathrm{Ca}$ and $\mathrm{P}$ calculated according to the DLG and INRA systems equaled, respectively: $\mathrm{Ca}, 60-64$ and $62-65 \%$;, $42-57$ and $65-87 \%$. Serum $\mathrm{Ca}$ and $\mathrm{P}$ levels in the cows corresponded to the retention of these elements.

KEY WORDS: dry cows, mincrals, fecding standards, absorption, blood, colostrum

\section{INTRODUCTION}

Intake and absorption play a decisive role in meeting the mineral requirements of all animals (Anke and Grun, 1982; Hemingway, 1982), but in the case of 
ruminants, the conditions prevailing in the rumen are an additional determinant (Belibasakis and Triantos, 1991). The mineral requirements set in various feeding systems differ considerably, especially in respect to calcium and phosphorus (ARC, 1980; INRA, 1988; NRC, 1978, 1989; DLG, 1986; Polish standards, 1985, 1993). The values used to calculate net requirements differ depending on the system and pertain to the way which endogenous losses are calculated, e.g. in the case of phosphorus, or to the degree of utilization of a given component, e.g. calcium. In earlier studies, endogenous losses were correlated with the weight of the animal (Field, 1983). Currently, it is believed that the intake of dry matter has a greater effect on these losses since calcium and phosphorus are excreted mainly with faeces. According to the NRC standards (1989), endogenous calcium losses per kilogram dry matter equial $1.54 \mathrm{~g}$, while according to the GfE standards (1992), these losses are estimated as $1 \mathrm{~g} / \mathrm{kg}$ dry matter. According to the same standards, phosphorus losses are also accepted as $1 \mathrm{~g} / \mathrm{kg}$ dry matter.

When calculating the calcium requirement, a maximum utilization of $68 \%$ was assumed in the ARC system (1980), i.e. almost twice as much as in the INRA standards (1988). Recently, calcium utilization coefficients were decreased by $1 / 5$ in the English AFRC standards (1991) in comparison with the ARC requirements (1980), while in the German standards, they were raised from 40 (GfE, 1986) to $50 \%$ (GfE, 1992). The phosphorus utilization coefficient was also changed in the German standards from 60 to $70 \%$, which led to smaller differences between the ARC and GfE standards. The differences in phosphorus requirements stem mainly from difficulties in precisely determining endogenous $P$.

Because the phosphorus and calcium requirements differ among standards, their $\mathrm{Ca}: \mathrm{P}$ ratios also vary: this ratio in the AFRC norms is about $1: 1$, in the INRA system $(1988), 2: 1$; in the NRC $(1978,1988)$ and DLG standards, about 1:5. The studies by Ferrell et al. (1982) and Rohr (1989) played an important role in developing requirements for dry cows.

The purpose of these experiments was to determine calcium and phosphorus absorption in dry cows fed according to INRA, DLG and NRC standards and to determine the optimal values for cows in Poland.

\section{MATERIAL AND METHODS}

The experiment was conducted on 24 Black-and-White Lowland cows with an average body weight of about $600 \mathrm{~kg}$ and milk yield of $5000 \mathrm{~kg}$ that, during the dry period (about 60 days before calving), were allotted to 3 dietary groups of 8 cows each, using an analogue method taking into account successive lactation, I to IV. The animals were maintained on straw litter and fed maize silage, 
TABLE 1

Design of experiment

\begin{tabular}{lccc}
\hline & & Groups & \\
\cline { 2 - 4 } Feedstuff and additives & I INRA & II DLG & III NRC \\
\hline Maize silage, kg & 25.0 & 21.0 & 20.0 \\
Meadow hay, kg & 4.0 & 3.0 & 3.0 \\
Wheat straw, kg & 1.0 & 1.0 & 1.0 \\
Ground barlcy, kg & 0.4 & 0.4 & 0.4 \\
Premix', g & 100 & 100 & 100 \\
Ammonium phosphate, g & 43 & 43 & 9 \\
Limestone, g & 25 & - & - \\
Common salt, g & 25 & 25 & 25 \\
& & & \\
In the daily ration: & & 9078 & 8808 \\
dry matter, g & 10937 & 811 & 760 \\
crude protein, g & 984 & 580 & 565 \\
PDIE, g & 705 & 479 & 465 \\
PDIN, g & 586 & 48.27 & 46.87 \\
NEL, MJ & 58.23 & 7.04 & 6.83 \\
UFL, & 8.50 & $10.74 \mathrm{LFU}$ & $10.43 \mathrm{LFU}$ \\
FFV (roughages) & $12.92 \mathrm{LFU}$ & $38(38)$ & $38(36)$ \\
Ca, g & $57(57)$ & $31(30$ & $22(20)$ \\
P, g & $35(33)$ & $18(14)$ & $18(16)$ \\
Mg, g & $22(13)$ & 14 & 14 \\
Na, g & 15 & 520 & 512 \\
Zn, mg & 592 & 84 & 82 \\
Cu, mg & 102 & & \\
\hline
\end{tabular}

in parenthesis-requirements according to different standards

1 - wheat bran; per $1 \mathrm{~kg}$ : vit. A - 500000 IU; vit. D3-50000 IU; vit. E - $2000 \mathrm{IU}$; (Co) - $10 \mathrm{mg}$; (Se) - $15 \mathrm{mg}$; (J) - $30 \mathrm{mg}$; (Zn) - $2000 \mathrm{mg}$

ground barley (Table 1). The cows were fed individually, twice daily, with a diet that covered their requirements according to the appropriate standards. All of the animals received common salt and polfamix, prepared according to own recipe, as mineral and vitamin-mineral supplements (Table 1). In order to cover the animals' calcium and phosphorus requirements, the diets of the animals fed according to the INRA (group I), DLG (group II) and NRC (group III) standards were supplemented with limestone and ammonium phosphate.

Digestibility-balance studies were carried out 3-4 weeks before calving using a conventional method on 12 cows ( 4 from each group). The preliminary period lasted 28-32 days, the collection period - 7 days. During this time, feed, additives and refusals were weighed daily. Daily faeces and urine collections were made, using $10 \%$ total volume (preserved with $10 \% \mathrm{HCl}$ ) for chemical analysis. Colost- 
TABLE 2

Nutrients and mineral contents in feedstuffs

\begin{tabular}{lcccc}
\hline & \multicolumn{4}{c}{ Feedstuff } \\
\cline { 2 - 5 } & Maize silage & Meadow hay & Ground barley & Wheat straw \\
\hline Nutrients, \% & & & \\
Dry matter & 24.6 & 84.78 & 85.61 & 88.21 \\
$\quad$ Crude protein & 2.16 & 8,63 & 10.09 & 2.04 \\
Ether extract & 0.98 & 1.48 & 2.21 & 1.09 \\
Ash & 2.27 & 6.17 & 2.78 & 4.75 \\
Crude fibre & 6.32 & 23.79 & 4.33 & 33.31 \\
N-free extractives & 12.93 & 44.71 & 66.20 & 47.02 \\
NEL (cnergy), MJ & 1.40 & 4.36 & 7.49 & 2.79 \\
Mincrals & & & & \\
Ca, g & 1.29 & 3.06 & 1.35 & 2.32 \\
P,g & 0.63 & 1.97 & 3.20 & 0.46 \\
Mg, g & 0.69 & 0.89 & 1.26 & 0.68 \\
Na, g & 0.12 & 0.44 & 0.33 & 0.18 \\
Cu, mg & 2.47 & 8.41 & 8.08 & 3.69 \\
Zn, mg & 8.60 & 36.84 & 51.54 & 8.60 \\
\hline
\end{tabular}

TABLE 3

Coefficients of apparent digestibility of nutrients and nitrogen balance

\begin{tabular}{|c|c|c|c|c|}
\hline \multirow{2}{*}{ Indices } & \multicolumn{3}{|c|}{ Groups } & \multirow{2}{*}{ SEM } \\
\hline & I INRA & II DLG & III NRC & \\
\hline \multicolumn{5}{|c|}{ Coefficients of apparent digestibility, $\%$} \\
\hline organic matter & 65.3 & 61.3 & 62.6 & 3.8 \\
\hline crude protein & 46.8 & 51.4 & 50.3 & 3.8 \\
\hline ether extract & 77.0 & 70.9 & 74.1 & 3.8 \\
\hline crude fibre & $67.7^{\mathrm{Aa}}$ & $56.5^{\mathrm{Bb}}$ & $61.1^{\mathrm{a}}$ & 5.7 \\
\hline $\mathrm{N}$-free extractives & $70.6^{\mathrm{A}}$ & $61.4^{\mathrm{B}}$ & $66.1^{\wedge B}$ & 5.1 \\
\hline \multicolumn{5}{|l|}{ Nitrogen balance } \\
\hline $\mathrm{N}$-intake, $\mathrm{g}$ & $147.3^{\mathrm{A}}$ & $126.8^{\mathrm{B}}$ & $119.9^{\mathrm{B}}$ & 12.7 \\
\hline $\mathrm{N}$-faeces, $\mathrm{g}$ & $78.3^{\mathrm{A}}$ & $61.6^{\mathrm{B}}$ & $59.6^{\mathrm{B}}$ & 10.0 \\
\hline $\mathrm{N}$-urine, $\mathrm{g}$ & $39.3^{\mathrm{A}}$ & 40.0 & 38.2 & 4.70 \\
\hline $\mathrm{N}$-retention, $\mathrm{g}$ & 29.7 & 25.2 & 22.1 & 8.86 \\
\hline$\%$ & 20.2 & 19.9 & 18.4 & 4.0 \\
\hline
\end{tabular}

$\mathrm{a}, \mathrm{b}=\mathrm{P}<0.05 ; \mathrm{A}, \mathrm{B}=\mathrm{P}<0.01$ 
using $10 \%$ total volume (preserved with $10 \% \mathrm{HCl}$ ) for chemical analysis. Colostrum samples from the first milking were taken from each cow after calving.

The nutrients content of feeds, faeces and urine were, determined using conventional methods, minerals were determined after previous mineralization using hydrochloric and perchloric acids by atomic absorption (Zeiss AAS-3), while phosphorus by spectrophotometric measurement of complex with vanadate. At the end of the experiment blood was sampled from the jugular vein for determination of mineral elements in serum ( $\mathrm{Ca}$, inorganic $\mathrm{P}, \mathrm{Mg}, \mathrm{Zn}, \mathrm{Cu}$ ) and glucose using kits from POCh Gliwice (Poland).

The results were subjected to statistical analysis using variance analysis and Duncan's multiple interval test.

\section{RESULTS}

The chemical composition of feeds is given in Table 2.

The digestibility coefficients of feed nutrients were not high, which results both from the physiological status of the cows and feeding regimen (Table 3 ). The digestibility of raw fibre and $\mathrm{N}$-free extractives was higher $(\mathrm{P}<0.01)$ in group $\mathrm{I}$, fed according to INRA standards. The lowest carbohydrate digestibility coefficients were found in the animals in group II, fed according to the DLG system.

Nitrogen intake differed considerably between groups which was the result of different amounts of offered feed, in accordance with the different systems. Cows in group I (INRA) excreted more nitrogen in faeces than in the other groups, while urinary nitrogen excretion was similar. Nitrogen retention was positive in all of the groups, regardless of the feeding standards used; the slight differences stemmed from the differences in nitrogen intake.

Because of the differences in feed intake resulting from different feeding standards, cows in group I (INRA) consumed the most Ca. Significantly higher $(\mathrm{P}<0.05)$ calcium absorption and retention was found in this group. It should be noticed that only small amounts of Ca were excreted in urine (Table 4). Cows fed according to the NCR system (group III) ingested the least phosphorus $(\mathbf{P}<0.01)$. Apparent absorption of this element was low and ranged from 15 to $24 \%$, while retention from 3 to $7 \mathrm{~g} / \mathrm{d} / \mathrm{cow}$. Both absorption and retention of $P$ were significantly higher in the cows fed according to the INRA system than in the remaining groups. Only small amounts of phosphorus were excreted in urine. Based on the retention of calcium and phosphorus (Table 4), it can be concluded that both the amount of $\mathrm{Ca}$ and the $\mathrm{Ca}: \mathrm{P}$ ratio were optimal when feeding cows according to the INRA system. The high retention of calcium in the INRA 
TABLE 4

$\Lambda$ pparent absorption and $\mathrm{Ca}$ and $\mathrm{P}$ balance

\begin{tabular}{|c|c|c|c|c|}
\hline \multirow{2}{*}{ Indices } & \multicolumn{3}{|c|}{ Groups } & \multirow{2}{*}{ SEM } \\
\hline & I INRA & II DLG & III NRC & \\
\hline Ca intake, $\mathrm{g}$ & $54.7^{\mathrm{A}}$ & $39.4^{\mathrm{B}}$ & $38.8^{\mathrm{R}}$ & 8.2 \\
\hline \multicolumn{5}{|l|}{ Ca output, $\mathrm{g}$} \\
\hline in faeces & $29.4^{\mathrm{A}}$ & $23.2^{\mathrm{B}}$ & $23.8^{\mathrm{B}}$ & 3.4 \\
\hline in urine & 0.2 & 0.3 & 0.3 & 0.2 \\
\hline Ca retention, $\mathrm{g}$ & $25.1^{\mathrm{a}}$ & $15.9^{b}$ & $14.7^{\mathrm{b}}$ & 5.4 \\
\hline$\%$ & $45.9^{\mathrm{a}}$ & 40.4 & $37.9^{b}$ & 4.6 \\
\hline absorption, $\%$ & $46.3^{\mathrm{A}}$ & 41.2 & $38.7^{\mathrm{B}}$ & 4.4 \\
\hline P intake, g & 33.2 & 29.9 & 21.6 & 5.3 \\
\hline \multicolumn{5}{|l|}{ P output $g$} \\
\hline in faeces & $25.1^{\mathrm{a}}$ & $25.7^{\mathrm{a}}$ & $17.7^{\mathrm{b}}$ & 4.8 \\
\hline in urine & 1.1 & 1.1 & 1.1 & 0.5 \\
\hline $\mathrm{P}$ retention, $\mathrm{g}$ & $7.0^{\mathrm{a}}$ & $3.1^{\mathrm{B}}$ & $2.8^{\mathrm{B}}$ & 2.8 \\
\hline$\%$ & $21.1^{\mathrm{a}}$ & 10.4 & 12.9 & 8.2 \\
\hline absorption, \% & $24.4^{\mathrm{Aa}}$ & $14.3^{\mathrm{b}}$ & $18.1^{\mathrm{b}}$ & 5.7 \\
\hline
\end{tabular}

$\mathrm{a}, \mathrm{b}=\mathrm{P}<0.05 ; \mathrm{A}, \mathrm{B}=\mathrm{P}<0.01$

system is also the result of the highest dietary calcium intake. True absorption of calcium and phosphorus was also calculated, taking into account endogenous losses according to the INRA and DLG systems. According to INRA (1988), endogenous $\mathrm{Ca}$ and $\mathbf{P}$ are calculated per kilogram body weight and equal $15 \mathrm{mg}$ for Ca and $25 \mathrm{mg}$ for P, while according to the DLG standards (GfE, 1986) endogenous losses are calculated against the amount of consumed feed dry matter and equal $1 \mathrm{~g} \mathrm{Ca}$ and $1 \mathrm{~g} \mathrm{P}$ per kilogram DM. Calcium absorption calculated according to INRA ranged between 62 to $65 \%$, while according to DLG, from 60 to $64 \%$. Phosphorus absorption differed considerably and equaled $65-87 \%$ and $42-57 \%$, respectively (Table 8 ).

The $\mathrm{Mg}$ intake (Table 5) was highest in cows fed according to the INRA system, lower in the DLG and NRC systems. Excretion of this major element in faeces was similar using the INRA and DLG systems (groups I and II) and significantly lower $(\mathrm{P}<0.05)$ in the $\mathrm{NRC}$ group (III). The urinary $\mathrm{Mg}$ content indicates that the cows were well supplied with this element. Magnesium absorption ranged from 24 to $31 \%$, retention from 2 to $4 \mathrm{~g} / \mathrm{d} / \mathrm{cow}$. Significantly higher $\mathrm{Mg}$ retention was found in group I (INRA).

Sodium uptake differed among the compared groups. The cows in group I (INRA) consumed the most sodium $(P<0.05)$. Sodium excretion in faeces and urine were, however, similar in all of the groups. The values obtained for $\mathrm{Na}$ absorption and retention ranged from 78 to $81 \%$ and from 9.2 to $9.6 \mathrm{~g} / \mathrm{d} / \mathrm{cow}$. They were similar in all of the groups regardless of the feeding system used. 
TABLE 5

Apparent absorption and digestibility of $\mathrm{Mg}$ and $\mathrm{Na}$

\begin{tabular}{lcccc}
\hline \multirow{2}{*}{ Indiccs } & \multicolumn{3}{c}{ Groups } & SEM \\
\cline { 2 - 4 } & I INR $\Lambda$ & II DLG & III NRC & \\
\hline Mg intake, g & $20.2^{\mathrm{A}}$ & $17.57^{\mathrm{B}}$ & $17.12^{\mathrm{B}}$ & 1.7 \\
Mg outpul in faeces, g & $14.0^{\mathrm{a}}$ & $13.3^{\mathrm{a}}$ & $12.0^{\mathrm{b}}$ & 1.8 \\
in urine, g & 2.3 & 2.4 & 3.3 & 0.9 \\
Mg retcntion, g & $3.9^{\mathrm{a}}$ & $1.9^{\mathrm{b}}$ & $1.8^{\mathrm{b}}$ & 1.9 \\
\% & $19.1^{\mathrm{a}}$ & $10.8^{\mathrm{b}}$ & $10.6^{\mathrm{b}}$ & 9.1 \\
absorption, \% & 30.7 & 24.2 & 30.1 & 12.0 \\
Na intake, g & $14.4^{\mathrm{a}}$ & $13.7^{\mathrm{b}}$ & $13.5^{\mathrm{b}}$ & 0.5 \\
Na output & & & & \\
in faeces, g & 3.2 & 3.0 & 2.6 & 1.0 \\
in urine, g & 1.5 & 1.3 & 1.7 & 0.3 \\
Na retention, g & 9.6 & 9.4 & 9.2 & 0.9 \\
\% & 67.0 & 68.5 & 68.0 & 6.8 \\
absorption, \% & 77.7 & 78.2 & 80.9 & 6.8 \\
\hline
\end{tabular}

$\mathrm{a}, \mathrm{b}=\mathrm{P}<0.05 ; \mathrm{A}, \mathrm{B}=\mathrm{P}<0.01$

Zinc uptake was similar (Table 6) and rather high, equaling about $50 \mathrm{ppm}$ per $\mathrm{kg}$ dry matter. Absorption of zinc in all of the cows, regardless of the feeding system, was high and ranged from 74 (DLG, group II) to $78 \%$ (INR $\Lambda, N R C$, group I and II). Zn retention ranged from 322 in group $I I$ to $371 \mathrm{mg} / \mathrm{d} /$ cow in group I.

TABLE 6

Apparent absorption and $\mathrm{Zn}$ and $\mathrm{Cu}$ balance

\begin{tabular}{lcccc}
\hline Indices & \multicolumn{3}{c}{ Groups } & \multirow{2}{*}{ SEM } \\
\cline { 2 - 4 } & I INRA & II DLG & III NRC & \\
\hline Zn intake, mg & 518 & 475 & 470 & 31.7 \\
Zn output, mg & & & & \\
$\quad$ in faeces & 116 & 123 & 101 & 40.1 \\
$\quad$ in urine & 31 & 30 & 34 & 7.3 \\
Zn retention, mg & 371 & 322 & 335 & 42.3 \\
$\quad \%$ & 71.6 & 67.8 & 71.3 & 8.2 \\
$\quad$ absorptiof 9 & 77.6 & 74.1 & 78.5 & 7.7 \\
Cu intake, mg & $91.2^{\mathrm{a}}$ & $78.5^{\mathrm{b}}$ & $77.7^{\mathrm{b}}$ & 9.5 \\
Cu output, mg & & & & \\
$\quad$ in faeces & 21.9 & 28.0 & 25.0 & 5.7 \\
$\quad$ in urine & 9.8 & 7.4 & 10.9 & 3.5 \\
Cu retention, mg & $59.5^{\mathrm{A}}$ & $43.0^{\mathrm{B}}$ & $41.7^{\mathrm{B}}$ & 10 \\
$\quad$ absorption, \% & $65.2^{\mathrm{a}}$ & $54.8^{\mathrm{b}}$ & $53.7^{\mathrm{b}}$ & 7.5 \\
\hline
\end{tabular}

$\mathrm{a}, \mathrm{b}=\mathrm{P}<0.05 ; \mathrm{A}, \mathrm{B}=\mathrm{P}<0.01$ 
TABLE 7

Blood and Serum indices of dry cows

\begin{tabular}{lcccc}
\hline Indices & \multicolumn{3}{c}{ Groups } & \multirow{2}{*}{ SEM } \\
\cline { 2 - 3 } & I INRA & II DLG & III NRC & \\
\hline Glucose, mmol $/ 1$ & 2.2 & 2.3 & 2.2 & 0.2 \\
Urea, mmol $/ 1$ & 4.1 & 3.6 & 3.2 & 0.6 \\
$\mathrm{Ca}, \mathrm{mmol} / 1$ & 2.4 & 2.6 & 2.6 & 0.3 \\
Inorganic P, mmol/1 & 1.8 & 1.7 & 1.7 & 0.2 \\
$\mathrm{Mg}, \mathrm{mmol} / 1$ & 0.9 & 1.0 & 0.9 & 0.1 \\
$\mathrm{Cu}, \mu \mathrm{mol} / 1$ & $11.2^{\mathrm{a}}$ & $9.9^{\mathrm{h}}$ & $11.2^{\mathrm{a}}$ & 0.9 \\
$\mathrm{Zn}, \mu \mathrm{mol} / 1$ & $31.5^{\mathrm{a}}$ & $28.0^{\mathrm{Ah}}$ & $34.3^{\mathrm{Bn}}$ & 4.0 \\
\hline
\end{tabular}

$\mathrm{a}, \mathrm{b}=\mathrm{P}<0.05 ; \mathrm{A}, \mathrm{B}=\mathrm{P}<0.01$

Copper intake ranged from 8 to $9 \mathrm{ppm}$ per $\mathrm{kg} \mathrm{DM}$ and was greater $(\mathrm{P}<0.05)$ in group I (INRA) than in the remaining groups, which is corroborated by the higher apparent absorption $(\mathrm{P}<0.05)$ as well as by the highest $(\mathrm{P}<0.01)$ retention of $\mathrm{Cu}$ in this group. Absorption of copper was high, from 64 to $80 \%$, retention equaled from 42 (group III NRC) to $59 \mathrm{mg} / \mathrm{d} / \mathrm{cow}$ (group I INRA).

The biochemical composition of blood and serum is given in Table 7. The copper and zinc levels were higher $(\mathrm{P}<0.05)$ in the serum of cows in groups I and III (INRA and NRC) in comparison with group II (DLG).

The highest dry matter, crude protein, urea, zinc and copper levels were found in the colostrum of cows fed according to the INRA system (group I; Table 9). The phosphorus content was also higher $(\mathrm{P}<0.05)$ in this group, which clearly correlated with its retention in group I (INRA). The least dry matter, crude protein and fat was in the colostrum of cows fed according to the NRC system (group III).

TABLE 8

True absorption of $\mathrm{Ca}$ and $\mathrm{P}, \%$, calculated according to the INRA and DLG methods (taking into account endogenous losses)

\begin{tabular}{lccccc}
\hline \multirow{2}{*}{ According to } & Element & \multicolumn{3}{c}{ Groups } & \multirow{2}{*}{ SEM } \\
\cline { 3 - 4 } & & I INRA & II DLG & III NRC & \\
\hline DLG & & & & & \\
& $\mathrm{Ca}$ & 64.0 & 62.7 & 60.4 & 3.4 \\
INRA & $\mathrm{P}$ & 53.6 & 42.5 & 57.0 & 9.9 \\
& & & & & \\
& $\mathrm{Ca}$ & 65.4 & 64.2 & 62.0 & 4.3 \\
& $\mathrm{P}$ & $64.7^{\mathrm{a}}$ & $70.0^{\mathrm{a}}$ & $87.3^{\mathrm{b}}$ & 13.2 \\
\hline
\end{tabular}

$\mathrm{a}_{1} \mathrm{~b}=\mathrm{P}<0.05$ 
TABLE 9

Chemical composition of colostrum

\begin{tabular}{lcccc}
\hline \multirow{2}{*}{ Indices } & \multicolumn{3}{c}{ Groups } & \multirow{2}{*}{ SEM } \\
\cline { 2 - 4 } & I INRA & Il DLG & III NRC & \\
\hline Dry matter, \% & 24.2 & 22.9 & 20.0 & 3.2 \\
Crude protein, \% & 13.9 & 11.9 & 10.6 & 3.0 \\
Fat, \% & 7.4 & 7.3 & 6.2 & 1.7 \\
Lactose, \% & 2.3 & 2.2 & 2.9 & 0.7 \\
Urea, \% & 8.9 & 6.5 & 7.0 & 1.9 \\
$\mathrm{Ca}, \mathrm{g} / \mathrm{kg}$ & 1.6 & 1.4 & 1.6 & 0.3 \\
$\mathrm{P}, \mathrm{g} / \mathrm{kg}$ & $1.7^{\mathrm{a}}$ & $1.3^{\mathrm{a}}$ & 1.5 & 0.3 \\
$\mathrm{Mg}, \mathrm{g} / \mathrm{kg}$ & 0.3 & 0.2 & 0.3 & 0.1 \\
$\mathrm{Na}, \mathrm{g} / \mathrm{kg}$ & 0.6 & 0.7 & 0.9 & 0.4 \\
$\mathrm{Cu}, \mathrm{mg} / \mathrm{kg}$ & 1.5 & 1.4 & 1.3 & 0.3 \\
$\mathrm{Zn}, \mathrm{mg} / \mathrm{kg}$ & 24.3 & 22.3 & 21.8 & 6.6 \\
\hline
\end{tabular}

$\mathrm{a}, \mathrm{b}=\mathrm{P}<0.05$

\section{DISCUSSION}

The digestibility of the nutrients and nitrogen retention in cows fed according to the tested feeding standards (Table 3 ) point to the superiority of the INRA system over the DLG and NRC systems, but it must be noticed that nitrogen retention in the cows of all of the groups was positive, despite some differences in nitrogen content of the rations. Significant differences $(\mathrm{P}<0.01)$ were found in nitrogen absorption in cows fed according to the INRA and NRC systems, with absorption being lower in the latter, even in comparison with the DLG system.

As expected, calcium retention was higher in group I (INRA) since the calcium content of this ration was the highest. Differences in Ca retention were significant $(\mathrm{P}<0.05)$; in the DLG and NRC system Ca retention equaled about $15 \mathrm{~g} / \mathrm{d}$, while in the INR $\Lambda$ system, $25 \mathrm{~g} / \mathrm{d}$. Calcium absorption was within the range given in the NRC standards (1988) and by Hibbs and Conrad (1983). According to American and French authors, average calcium absorption in dry and lactating cows is about 38\% (Jimenez, 1980; Cathcart et al., 1983; Gueguen et al. 1987).

The absorption of phosphorus was rather low. Similarly as in the case of calcium, $\mathbf{P}$ absorption in cows fed according to the INRA system was highest. The difference was highly significant against that in cows fed according to the DLG system and significantly different from those fed according to the NRC system. Phosphorus retention was also low and equaled from between 3 to $7 \mathrm{~g}$. A significantly higher value was obtained using the INRA system. The ratio of 
phosphorus to calcium retention did not equal 1:1.7, as given by Hibbs and Conrad (1983). According to the American standards (NRC, 1989), P absorption in cows is estimated at about $50 \%$. The low absorption and retention of $\mathrm{P}$ in terms of all of the examined standards may be the result of the rather low $\mathbf{P}$ supply in the rations for dry cows and large endogenous losses of this major element. Under these conditions, the values obtained in this study for both digestibility and retention of $P$ seem appropriate. It should be noticed that all of the obtained values of $\mathrm{Ca}$ and $\mathrm{P}$ absorption seem considerably lower than the absorption of the same major elements by cows after calving. These results have been confirmed by Kinal et al. (1995) in lactating cows. True absorption of calcium calculated according to the INRA and DLG methods was similar and ranged between 62 to $65 \%$. These values are higher than those given for lactating cows in the INRA system (30-35\%) and from true calcium absorption assumed in the GfE $(50 \%)$. The results obtained for true absorption of calcium correspond with the results of a study carried out in Great Britain by Field (1983), in which he demonstrated that when calcium is supplied very scarcely, its absorption rises to $70 \%$, while with a large excess, calcium absorption drops to $30 \%$. The Ca doses used in the current study should be viewed as very scarce, therefore the absorption of this major element must have been high.

The values of true phosphorus absorption were distinctly higher when the INRA system was used. In groups I (INRA) and II (DLG), absorption was close to values accepted for lactating cows. When small doses of phosphorus were given (the NRC system), $P$ absorption was higher. When assuming a $P$ retention value according to the DLG and NRC systems, it was shown that absorption of this element was on the borderline requirement of the developing fetus, while in the INRA system, P retention was double the fetal requirement (Rohr, 1989).

Magnesium retention was higher when the INRA system was used $(P<0.05)$. The results obtained in this study are confirmed by those of Jimenez (1980), Stec (1985), Teller and Godean (1987). According to the ARC system (1980), true absorption of magnesium from grass and hay in cows ranged from 12 to $37 \%$.

Absorption and retention of sodium was similar in all of the groups. According to NRC data (1989) $0.1 \% \mathrm{Na}$ in the dry matter of a ration for dry cows gives a positive sodium balance.

Absorption and retention of zinc was similar in all of the groups, which resulted from similar $\mathrm{Zn}$ contents in the rations. Miller (1975) points out that $\mathrm{Zn}$ absorption depends on the ration's content of phosphorus, copper and vitamin D. In the case of copper, high absorption and retention of this element was found, especially in cows fed according to the INRA system, but the obtained values were higher than those given in the ARC requirements (1988). According to Roy (1988), Cu utilization in lactating cows ranges from 5 to $10 \%$ of the amount in the ration. 
Most of the carbohydrate, protein and mineral metabolism indices in the blood and serum of dry cows were within normal physiological range. The glucose level was rather low in group I (INRA), while the urea level in this group was highest. These values may indicate that the energy and protein levels are not completely balanced in this ration. In the remaining two groups the glucose and urea levels were similar and within normal values.

A reliable indicator of the degree of coverage of the mineral requirement in cows is the mineral level in blood and colostrum. The blood Ca level in this experiment was relatively high, while the level of inorganic $\mathrm{P}$ rather low, which corresponds with the obtained retention values of these elements. Kruczyńska (1992) also found a high serum Ca level in dry cows, while the data reported by Lotthammer (1989) indicate that the physiological minimal serum Ca level is $2.4 \mathrm{mmol} / \mathrm{l}$ for cows after calving. According to Tremblay and Baird (1991) the minimum level are, $2.05 \mathrm{mmol} / \mathrm{l}$ for $\mathrm{Ca}$ and $1.19 \mathrm{mmol} / 1$ for $\mathrm{P}$. The magnesium level in all of the groups should be considered good and is similar to the values obtained by Kruczyńska (1992). The serum zinc level was rather high, while the copper level was low. The high serum $\mathrm{Zn}$ level can perhaps be the effect of its high concentration in the ration. These values were similar to those reported by Kruczyńska (1992).

The highest dry matter, protein and fat contents in colostrum were found in cows from group I (INRA). The lowest values were in cows fed according to $\mathrm{NCR}$ (gr. III) standards, and may be the result of the rather scarce ration used in this system. The Ca content in colostrum was both similar in all of the groups and similar to the values found by Strusińska (1994). In the case of phosphorus, its higher level was found in cows of group I (INRA) in comparison with the colostrum from cows fed according to DLG standards (group II). The magnesium, copper and zinc levels in colostrum of cows fed using the INRA system were also somewhat higher than the values found in group II (DLG), although these differences were not statistically significant. The relatively high copper level, higher than Strusińska reports in her study (1994), is noteworthy.

\section{CONCLUSIONS}

The results indicate providing calcium and phosphorus according to the INRA (1988) system requirements leads to superior organic nutrient digestibility, absorption of minerals and colostrum composition.

Apparent absorption of calcium in dry cows are similar to these values in cows in the peak of lactation, while the apparent absorption of phosphorus is considerably lower. 
The values of true calcium absorption calculated according to the INRA and DLG systems were similar and higher than recommended in the INRA system. The true absorption of phosphorus was closer to the values accepted in the INRA system, although there were differences between the DLG and INRA systems.

Taking into account the very low phosphorus retention found using the DLG and NRC systems and the unreduced absorption of calcium in cows fed according to the INRA system, it should be concluded that under Polish conditions, the INRA system provides the best coverage of calcium and phosphorus requirements of dry cows.

\section{REFERENCES}

AFRC - Agricultural and Food Research Council, 1991. Technical Committee on Responses to Nutrients. Report No 6. Reappraisal of the calcium and phosphorus requirement of sheep and cattle. Nutr. Abstr. Rev., Scr. B, 61, 573-612

ARC - Agricultural Research Council, 1980. The Nutrient Requirements of Ruminant Livestock. Commonwealth Agricultural Bureaux, Farnham Royal

Anke M., Grün M., 1982. Erfahrungen, Ergebnissc, Entwicklungen. Mineralstoffe 6. 1-3

Belibaskis N.G., Triantos A., 1991. Effects of sodium carbonate on milk yicld, milk composition and blood components of dairy cows in early lactation. J. Dairy Sci. 74, 467-472

Cathcart F.B., Shelford J.A., Peterson R.C., 1983. The effects of calcium carbonate on the apparent digestibility, serum concentration and apparent retention of dietary minerals in dairy cattlc. Can. J. Anim. Sci. 63, 173-180

Ferrel C.L., Laster D.B., Prior R.L., 1982. Mineral accertion during prenatal growth of cattle. J. Anim. Sci 54, 618-624

Field A.C., 1988. A reviev of requirements of dairy and beef cattle for major elements. Prod. Sci. 10, 327-338

Gesselschaft für Ernährungsphysiologie, Ausschiuß für Bedarfsnormen, 1986, 1992. Encrgic- und Nährstoffbedarf landwirtschaftlicher Nutzticre, 3. Milchküche und Aufzuchtrinder, DLG Frankfurt/Main

Gucguen M.L., Durand Meschy F., 1987. Apports recommendes en elements mineraux majcrus pour les ruminanst. Bull Tech. CRZN Theix. INRA, 70, 105-112

Iemingway R.G., 1982. Meeting the mincral requirements of cattle in practical feeding system. XXXIII Annual Mecting of the EAAP, $2 / 3$

Hibbs J.W., Conrad H.R., 1983. The relation of calcium and phosphorus intake and digestion and the effect of vitamin D feeding on the utilization of calcium and phosphorus by lactating cows. Res. Bull., 1150, Ohio State Univ., Ohio Agric. Res. and Develop. Center Wooster

Insitut National de la Recherche Agronomique, 1988. Ruminant nutrition. Recommended allowances and feed tables R.Jarrige (Editor), John Libleey and Co, Ltd., London

Jimenez A.D., 1980. Availability of minerals for ruminants. Fecdstuffs 52 (48), 16-19

Kinal S., Kornicwicz A.. Preś J., Chrząszcz. E., Kistowski T., 1995. Comparison of INRA, DLG and NRC norms for calcium, phosphorus and magnesium in the feeding of dairy cows (in Polish). Prace Mat. Zoot. (in press)

Kirk D.J., Greene L.W., Schelling G.T., Bycts F.M., 1995. Effects of monensin on monovalent ion metabolism and tissue concentrations in lambs. J. Anim. Sci. 60, 1479-1440 
Kruczyńska II., 1992. Tfficiency of mineral feeding of cows an calves in Wielkopolska conditions (in Polish). Rocz. AR. w Poznaniu, Rozpr. Nauk. № 231

Lotthammer K.H., 1989. Die fruchtbare Kuh. AJD 1073, 28-29

Miller W.J., 1975. Symposium. New concept and developments in trace element nutrition. Ncw concepts and developments in metabolism and homeostasis of inorganic elements in dairy cattle. A Review. J. Dairy Sci. 58, 1544-1560

National Research Council, 1978, 1989. Nutrient Requirements of Dairy Cattle., National Acad. Press, Washington, DC Feeding Norms for Animals, (in Polish), 1985. R.Ry (Editor), PWR i L, Warszawa

Feeding Norms for Cattle and Shcep, (in Polish), 1993. R. Ry (Editor). Rescarch Institute of Animal Production, Kraków

Rohr K., 1989. Energie- und Stoffansatz sowie Nährstoffbedarf gravider Rinder. Übers. Tierernähr. $17,27-46$

Roy J.H.B., 1980. The Calf. Butterworths, London-Boston

Stec A., 1985. Magnesiun effect and metabolism at ruminants (in Polish). Med. wet. 41, 753-756

Strusińska D., 1994. The content and utilization of minerals from different daily rations of cows in selected farms of Olsztyn region (in Polish). Acta Aciad. Agric. Technic. Olst., Zoot. 40, 1-54

Teller E., Godean J.M., 1987. Some observation about the magnesium absorption in cattle. J. Anim. Physiol. Anim. Nutr. 57, 16-22

Tremblay R.M., Baird J.D., 1991. Chronic copper poisoning in two Holstein cows. Cornell Vet. 81, 205-213

\section{STRESTCZFNIF}

Porównanie zapotrzebowania na wapú i fosfor u krów w okresie zasuszania według różnych norm

Dwadzieścia cztery krowy w okresie zasuszenia, podzielone na 3 grupy, żywiono kiszonką z kukurydzy, sianem ląkowym i śrutą jęczmienną pokrywając ich potræeby na składniki pokarmowe oraz wapri i fosfor wg norm INRA, DLG lub NRC.

Jako dodatki mineralne i mineralno-witaminowe stosowano Polfamiks, sporządzony wg receptury własncj, $\mathrm{NaCl}$, krcdę pastewną i fosforan amonu. Na 3-4 tygodnic przed ocieleniem na 4 krowach $z$ każdej grupy oznaczono strawność składników pokarmowych oraz bilans $\mathrm{N}$ i składników mineralnych ( $\mathrm{Ca}, \mathrm{P}, \mathrm{Mg}, \mathrm{Na}, \mathrm{Zn}$ i $\mathrm{Cu})$.

Strwaność składników pokarmowych oraz absorpcja $(46,3 \%)$ i retencja wapnia ( $25 \mathrm{~g} / \mathrm{dz} / \mathrm{szt}$.) były większe u krów żywionych wg norm INRA niż norm DLG i NRC. U krów wszystkich grup absorpcja (14-24\%) i retencja fosforu (3-7 g/dz/sz1) były niskie, przy czym najwyższe wartości otrzymano u krów żywionych wg systemu INRA. Absorpcja rzeczywista Ca i P obliczona wg systemu DLG i INRA wynosi a odpowiednio: Ca 60-64\% i 62-65\%, P $42-57$ i 65-87\%. Poziom Ca i P w surowicy krwi krów korespondował z wartościami retencji tych pierwiastków. 